statu nascendi". On this basis it is possible to get sympatric speciation resulting from chromosomal mutations. This theory contradicts one proposed by $\mathrm{Mayr}^{20}$, who claims that groups require to be geographically isolated from each other before speciation can occur.

Intra-specific chromosomo polymorphism was roported previously in Gerbillus pyramidum ${ }^{21}$ and Acomys cahirinus $^{22}$. However, hybridization experiments revealed that there are reproductive barriers between the different eytogenetic types, which indicates that an advanced stage in speciation has been reached by both groups ${ }^{23}$.

In a study of some species of Acomys ${ }^{23}$, Matthey observed two chromosome numbers in the members of a race of $A$. minous. A metacentric chromosome was found to be the cause of the difference; this would appear to represent a more complicated type of polymorphism than that explained by the Robertsonian type.

Centric fusion of telocentric chromosomes is a common characteristic of neoplastic tissues ${ }^{24}$ and is frequently found in cells in tissue culture ${ }^{25-26}$. As outlined by White ${ }^{8}$, and also pointed out by Ohno et al. ${ }^{25}$, a translocation of this type is of adaptive significance because now gene complexes are formed with different recombination values relative to the position of other gene loci. Iittle or no loss of genctic material is thought to occur and tho number of chromosome arms is constant as is the DNA content per nucleus.

The Robertsonian type of chromosome translocation which we have described in cattle is the first example of this type of rearrangement observed in domestic animals. INGemar Gustavsson

Department of Animal Geneties, Nutrition

and Hygiene,

Royal Veterinary College,

Stockholm, Sweden.

' Gustavsson, I., and Rockborn, G., Nature, 208, 990 (1964).

'Melander, Y., IIereditas, 45, 649 (1959).

${ }^{3}$ Melander, Y., Hereditas, 36, 233 (1950).

'Melander, Y., and Knudsen, O., Hereditas, 34. 505 (1953).

- Cleveland, R., Trans. Amer. Phil. Soc., 43, 809 (1953).

- Tjto, J. H., and Levan, A., Lunds Univ. Arsskrift, N.F. Avd. 2, 50, 39 (1954)

'Arakaki, D. T., and Sparkes, R. S., Cytogenetics, 2, 57 (1963). "White, M. J. D., Animal Cytology and Evolution, second ed. (Cambridge
University Press, 1954).

'Smith, S. G., Experientia, 12, 52 (1956); Nature, 17 \%, 386 (1956).

"Wahrman, J., Expericntia, 10, 176 (1954).

" Staiger, H., Chromosoma, 6, 419 (1954).

'2 Matthey, R., Les Chromosomes de Vertêbrés ( $\mathrm{F}$. Rouge, Lausanne, 1949).

"Bovey, R., Rev. Suisse Zool., 56, 341 (1949).

"Sharman, G. B., Nature, 177, 941 (1956)

"Ford, C. F., Hamerton, J. I., and Sharman, G. B., Nalure, 180, 392 (1957).

"Mcylan, A., Rev. Suisse Zool., 6", 258 (1960).

Matthey, R., and Meylan, A., Rev. Suisse Zool., 68, 223 (1961).

"Matthey, R., Rev. Suisse Zool., 70, 173 (1963).

Matthey, R., Experientia, 20, 1 (1964).

${ }^{24}$ Mayr, E., Animal Species and Evolution (Harvard University Press, Cambridge, 1963).

${ }^{21}$ Wahrman, J., and Zahavi, A., Nature, 175, 600 (1955).

22 Wahrman, J., and Zahavi, A., Bull. Res. Counc. Israël, 3, 265 (1953).

${ }^{23}$ Matthey, R., Chromosoma, 14, 468 (1963).

" Yosida, T. H., Proc. Jap. Acad. Sci., 31, 237 (1955).

Ohno, S., Kovacs, E. T., and Kinosita, R., J. Nat. Cancer Inst., 24, 1187 (1960).

"N Nelson-Rees, W. A., Kniazeff, A. J., and Darby, jun., N. B., J. Nat. Cancer Inst., 33, 347 (1964).

\section{Cuticular Structure in the Phalangida}

Apart from passing references such as that of Kastnor ${ }^{1}$ to tho cuticle of Trogulus, there is no information about the cuticular structure of the Phalangida. Histological investigations of the cuticle in three species of the Palpatores revealed a marked difference botween the cuticle of the dyspnoic Nemastoma lugubre (Mull) and the two eupnoic species Leiobunum rotundum (Lat.) and Phalangium opilio Lin.

In the two eupnoic species the situation is closely com. parable with that of insects ${ }^{2}$ and scorpions ${ }^{3}$. In cuticle with an overall thickness of $14 \mu$ thero is an endo-cuticular component $9 \mu$ thick and an exo-cuticle $4 \mu$ thick. The boundary between these two components is sharp and comprises an area which has little affinity for aniline blue, orange $G$ or acid fuchsin. It is perhaps comparable with the amber, or quinone tanned, exo-cuticle of scorpions ${ }^{3,4}$. The endocuticle differs from the relatively homogeneous exo-cuticle in its laminate structure. These laminae have a strong affinity for aniline blue and a slight residual affinity for acid fuchsin. In addition to these two major components there is, on the sclerites, an epi-cuticular layer corresponding to tho cuticulin of the epi-cuticle in scorpions. This is bordered externally by further thin epi-cuticular components.

In the arthrodial membranes the exo-cuticle is absent and they comprise a $2 \mu$ heterogeneous epi-cuticular component overlying the strongly laminate endocuticle which is uniformly stained by aniline blue.

In contrast the thick cuticle of Nemastoma lugubre comprises numerous laminae which are closely and regularly packed in the external $3 \cdot 5 \mu$ but less so in the internal $19 \mu$. In neither of these regions do the laminao have any marked affinity for tho foregoing stains. The most internal laminae do, however, have a slight positive reaction with acid fuchsin. Throughout the body the external closely packed laminate region contains the melanin which gives the species its characteristic colour. This is only lacking in the region of the two white spots.

In general the staining reactions of the arthrodial membranes, in which the epi-cuticular component is acid fuchsin positive and the endo-cuticular component. aniline blue positive, compares with the condition in other arthropods. In view of the fact that the endocuticle of Phalangium and Liobunum is also aniline blue positive with a residual affinity for acid fuchsin, it would seem that sclerotization only affects the exo-cuticle. The limitation of the acid fuchsin positivity in Nemastoma to the innermost lamina suggests that in this genus which, together with the Cyphophthalamae, Laniatores and Trogulidae, has long been known from superficial inspection to have a harder cuticle, this hardening is associated with the sclerotization of the entire thickness of the cuticle. It is further seen that in all three species the endo-cuticular component of the sclerites with its loosely laminated structure is more closely similar to the structure of the endo-cuticular component of the arthrodial membrane than is the case in scorpions where the laminae of the arthrodial membrane arc more marked in adult animals than are those of the endocuticle.

\section{A. Grainge \\ R. G. Pearson}

Zoological Laboratory, University of Liverpool.

1 Kastner, A., Handbuch der Zoologie, 3, 300 (1935).

${ }^{2}$ Wigglesworth, V. B., Ann. Rev. Entomol., 2, 37 (1957).

'Malek, S. R. A., Proc. Linn. Soc. Lond., 175, 101 (1964).

' Kennaugh, J., Quart. J. Micros. Sci., 100, 41 (1959).

\section{'Wavy-Fused' Mutants in the Medaka, Oryzias latipes}

AIDA $^{1}$ first reported the occurrence of wavy and fused vertebral mutations in the medaka. These characters are simple recessive to normal and are independent of all known genetic charactors and sex. The vertebral column of the wavy fish curves dorso-ventrally (Fig. $1 B$ ) and some centra of the fused fish are fused (Fig. $1 C$ ). Fig. $1 A D$ show the backbones of normal and wavy-fused fish. Recently, Takeuchi ${ }^{2}$ also reported a wavy mutant of the medaka which had appeared in the breeds of Yamamoto in Nagoya University and this mutant was used in tho present experiment. Although the wavy mutant is a simple recessive, the way in which it expresses itself suggests the presence of modifiers of the principal gene. The fused mutant used here originally appeared in Aida's breed and has been kept in the laboratory of Yamamoto (Nagoya). A detailed 